\title{
Student Academic Achievment : The Role of Emotional and Spiritual Intelligence
}

\author{
Addiniya Nurfarojandari ${ }^{1}$, Maftuhah Maftuhah ${ }^{2}$ \\ \{addiniya93@gmail.com ${ }^{1}$, maftuhah@uinjkt.ac.id ${ }^{2}$ \} \\ ${ }^{1}$ Postgraduate Program Attahiriyah Islamic University, Indonesia \\ ${ }^{2}$ Faculty of Islamic Education State Islamic University (UIN) Syarif Hidayatullah Jakarta, Indonesia
}

\begin{abstract}
In the education field student academic achievement is a reflection of the Academic proceeds. At the state of Academic proceeds student not only Academic about concept, they also learn how to control their emotion, helping people, social awareness, etc. The purpose of this research is to know : The Role of Emotional Intelligence and Spiritual Intelligence together to Student Academic Achievement Madrasah Aliyah Swasta (MAS) all around South Jakarta. A 100 student being sample from 10\% Population of Islamic Private High School Students all around South Jakarta, the method of sampling using simple random sampling. Emotional Intelligence is measured by Bar-On EQ125, Spiritual Intelligence is measured by SISRI-24, Student Academic Achievment is measured by Student Report Card. Researchers develop these three scales. Results show that there are. only $2.4 \%$ role of Emotional Intelligence and Spiritual Intelligence Student Academic Achievement while the rest by other variable.
\end{abstract}

Keywords: Emotional Intelligence, Spiritual Intelligence, Student Academic Achievement, Influence of Emotional Intelligence, Influence of Spiritual Intelligence.

\section{Introduction}

In the education field, the study is a positive transposition process which at the final stage will comes with several good results such as skills, and new knowledge. The study achievement is a reflection of the Academic proceeds. At the state of Academic proceeds student not only Academic about concept, they also learn how to control their emotion, helping people, social awareness, motivation, etc.

The presence of the phenomenon of a shift in attitudes and behaviors that are less appreciated values of humanity in society, then at this point required the attention of various parties. especially in education. Therefore emotional intelligence is very necessary to be developed in Academic

\subsection{Research Background}

As a researcher also educator some issue about academic achievement need to be solved. Traditionally, educators test for cognitive achievement using subjective measures such as grade point averages or objective scores from tests for verbal or mathematical domains. In the 
past few years, some educators have challenged this cognitive restriction. Research indicates that to develop the whole child, educators must nurture more than just cognitive intelligence. In fact, some findings suggest that a student must be encouraged to develop in multiple constructs to include "social, physical, intellectual, career, psychological, cultural, and spiritual development".

However, the presence of the phenomenon of a shift in attitudes and behaviors that are less appreciated values of humanity in society, then at this point required the attention of various parties. especially in education. Therefore emotional intelligence is very necessary to be developed in Academic

The results of research by psychologists in the USA (United States of America concluded that the success person in living a life is strongly supported by emotional intelligence (EQ) around $80 \%$, while the role of intellectual intelligence (IQ) is only $20 \%$. The center of IQ and EQ is spiritual intelligence (SQ).

Recent studies that advocate the importance of emotional intelligence on achievement [4] have also led some educators to explore the relationship between emotional intelligence and academic achievment. A relatively new concept called spiritual intelligence (SI) that encourages problem solving and critical existential thinking has recently come under serious consideration. Recent studies that involve SI have occurred in other countries. [1] And there are none research address emotional and spiritual intelligence as a one variable, also there are none researcher comes from Indonesia which is having a strongly spiritual culture. This research examined the role of Emotional and Spiritual Intelligence to academic achievement of high school students to analyze if there could be a possible relationship with achievement.

\subsection{Literature Review}

The indicator of the study process according to the provisions of the Education and Culture Republic Indonesia point. 104, 2014 "Assessment of study results by the educator is a process of collecting information/evidence of study accomplishment of the student's competency in spiritual attitude, social attitude, knowledge competency, and skill competency that planned and systematic, during and after the studying process."[2]. Assessment aspects comprise:

- Self-assessment

- Assignment assessment

- Project assessment

- Assessment by observation

- Daily examination marks

- End of term examination marks

- Academic achievement in attitude marks

- Academic achievement in knowledge marks

- Academic achievement in skill marks

The study process in school is thorough and complex. Many people have an opinion for reaching a great achievement in the study, somebody should have a high intelligence quotient(IQ), because intelligence is a potential weapon which will lead the study to become easier and in the meant time, it will resulting in an optimal study achievement. Meanwhile, as for the fact, not just a few people with IQ above the average is having a low achievement, and many people with average IQ is surpassed the study achievement with the people with IQ above the average. It's indicated IQ does not the only thing that affecting an individual's study process. Besides IQ, in terms of intelligence, another intelligence is also known, such as emotional intelligence, and spiritual intelligence. 
Emotional intelligence was first discovered in 1990 by psychologists Peter Salovey and John Mayer in Goleman [3] which defines emotional intelligence or EI is often referred to as "The set of parts of social intelligence that involves the ability to monitor social feelings that involve the ability of others, sort out everything and use this information to guide thoughts and actions"

According to Daniel Goleman emotions refer to a specific feeling and thought, a biological and psychological state and a set of tendencies to act. Emotion is the urge to act. Usually, emotions are reactions to stimuli from outside and inside the individual. For example emotion excited drive change a person's mood, so that physiologically seen laughing, sad emotions encourage someone to behave in tears.

According to Cooper and Sawaf [4], emotional intelligence is the ability to feel, understand and selectively apply emotional power and sensitivity as a source of energy and human influence. Emotional intelligence requires surveillance feelings, learn to recognize, appreciate the feelings in themselves and others and respond appropriately, effectively implement the emotional energy in everyday life.

According to Ary Ginanjar [5] Spiritual Intelligence commonly abbreviated as SQ is the foundation needed to function Intelligence Quotient (IQ) and Emotional Quotient (EQ) effectively. Even SQ is the highest intelligence because SQ is the foundation and source of other intelligence. The emergence of the term spiritual intelligence in education, for some people, might be considered as an answer to the situation.

Zohar and Marshal [6] said that spiritual intelligence is interpreted as intelligence that relies on the inner self that is associated with wisdom outside the ego or soul of consciousness. As an intelligence that is always used not only to determine the values that exist but also to creatively discover new values in life. If the spiritual quotient (SQ) has developed well, then it is a characteristic of people who have high spiritual intelligence (SQ).

Some scientific evidence about spiritual intelligence is presented by Zohar and Marshall in SQ, Spiritual Quotient, The Ultimate Intelligence. Two of them are: First, psychology/neurologist research, Michael Persinger in the early 1990s, and more recently in 1997 by neurologist VS Ramachandran and his team from California University, who discovered the existence of God Spot in the human brain has been built in. as a spiritual center located in the front part of the brain. While the second proof is Austrian neurologist research, Wolf Singer in the 1990s on his paper: The Binding Problem, which shows there are neural processes in the human brain that are concentrated on efforts to unite and give meaning to our life experiences. A neural network that literally "binds" our experiences together to "live more meaningfully". The next fact, Lan Mitroff and Elizabeth Denton wrote in their work entitled "a Spiritual Audit of corporate America: A Hard look at Spirituality, Religion and Values in the Workplace" that: "Most of the executive defined spirituality in much the same way - not as religion, but as "the basic desire to find purposes and meaning in one's life".

In the thesis compiled by King [7], there are four components of spiritual intelligence, each of which represents indicators as a measure of overall spiritual intelligence, namely Critical Existential Thinking (CET), Personal Meaning Production (PMP), Transcendental Awareness (TA), and Conscious State Expansion (CSE).

\section{A. .CET}

The first component of spiritual intelligence involves the ability to critically ponder the meaning, purpose, and other existential or metaphysical issues (for example, reality, nature, universe, space, time and death). In his instrument, King formulated this component on the element of existence, the meaning of events life after death, human relations and the universe, 
and concerning God or higher powers. However, research conducted by King does not refer to any particular religion or non-religion.

\section{B. PMP}

The second core component is defined as the ability to build personal meaning and purpose in all physical and mental experiences, including the ability to making and mastering life goals. Nasel in King agrees that spiritual intelligence involves the contemplation of the symbolic meaning of reality and personal experience to find the purpose and meaning in all life experiences. In his instrument, King formulates the components of the elements of the ability to adapt from the meaning and purpose of life and the reason for life, the meaning of failure, making decisions by the purpose of life, as well as the meaning and purpose of daily events.

\section{Transcendental awareness}

The third component involves the ability to see the transcendent dimensions of self, others, and the physical world (eg nonmaterial and connectedness) in the normal state as well as in the state of building the area of consciousness. Wolman in King describes transcendental awareness as the ability to feel the spiritual dimension of life, reflecting what was previously described as feeling a more real, more diffused and general presence from our special senses. In his instrument, King formulated this component to non-physical and non-material aspects, to be able to feel non-physical and non-material, understand the relationships between humans, define non-physical (spirit), quality of personality/emotions, and be able to focus yourself.

\section{CSE}

The final component of this model is the ability to entering the areas of spiritual awareness (for example, pure awareness, and unity) at its discretion. From a psychological perspective, the difference between transcendental awareness and the development of this awareness area is supported by Tart in King that transcendental awareness must occur during the normal conscious state, whereas the development of the awareness area includes the ability to overcome the conscious state and the higher area or spiritual.

Self-awareness (self-consciousness which is also often called self-awareness) is the main differentiator between people who have high spiritualism with those who do not. People who have a high awareness will always think several times in response to each situation, take a moment to understand what is hidden or real before showing the initial response. He always acted with calculation, consideration, and caution. In his instrument, King formulated this component into the elements of entering the area of consciousness, controlling the area of consciousness, moving within the area of consciousness, seeing problems in the area of consciousness, and developing techniques for the area of consciousness.

\section{METHODS}

The method used in this research is quantitative research, which is a process of finding the knowledge that uses data in the form of numbers as a tool for finding information about what you want to know. In general, quantitative research can be carried out as well as descriptive 
research. Quantitative research also can be in the form of relationship research or correlation research, quasi-experimental research and experimental research.

Before the researcher tests the hypothesis with the research instrument, the researcher examines the Research Instrument using the validity and reliability test using the SPSS 23 program.

Vaidity test in general is to find out whether the questionnaire used is really valid to measure the variables research. In general, there are two formulas or methods of validity testing, namely the Bevariate Pearson Correlation and the Correlated Item-Total Correlation, the Bevariate Pearson Correlation is one formula that can be used to test data validity with the SPSS program.

The reliability test is used to determine the consistency of the measuring instrument, whether the measuring device used is reliable and remains consistent if the measurement is repeated. In the SPSS program the method that is often used is to use the Cronbach's Alpha method

Hypothesis testing is using multiple linear regression analysis. All data processing will be carried out using SPSS 23 program. The measurement used to measure the degree of linear correlation is called the correlation coefficient denoted by the letter $r$. the magnitude of the correlation coefficient always lies between -1 and $+1(-1 \leq \mathrm{r} \leq+1)$, then:

1. $\mathrm{r}=+1$, means there is a perfect positive correlation between $\mathrm{X}$ and $\mathrm{Y}$

2. $\mathrm{r}=-1$, means there is a perfect negative correlation between $\mathrm{X}$ and $\mathrm{Y}$

3. $\mathrm{r}=0$, means there is no correlation between $\mathrm{X}$ and $\mathrm{Y}$

The purpose of correlation analysis is to measure the degree of the connection and how close the connection is. The steps used in testing the significance, in this case, use the productmoment correlation, including:

1. Determine the hypothesis, usually, the correlation significance test is carried out with the zero hypotheses (Ho). Ho is common for correlation reads "there is no correlation between variable $\mathrm{X}$ with variable $\mathrm{Y}^{\prime \prime}$

2. Choose the level of significance.

3. Comparing $r$ arithmetic with the $r$ table.

4. Make a decision: if the price or $r$ arithmetic $\geq r$ table, then Ho is rejected.

5. Conclusion

\section{a. Population and sample}

The population in this research are 21 privat high school at South Jakarta, While determining the number of samples taken by the regional sample method (cluster sampling), After knowing the number of samples taken in each region, researcher used the Proposional Random Sampling method, due to the varied number of students in each school so it was decided that only $10 \%$ of the total students would be taken and randomly selected, therefore the number of participant 100 students from 1003 students from 6 school respresenting subdistrict in Jakarta

\section{b. Data collection technique}

Then the respondents in this study amounted to 100 private Madrasah Aliyah students in South Jakarta.randomly $10 \%$ of 1003 MAS students selected in South Jakarta. With the proportional determination of Respondents in each area in South Jakarta each $10 \%$ of the total 
madrasa population. Researcher collected data directly from respondents, and all respondents $100 \%$ completed the questionnaire.

Data collection techniques in this study were adopted in two ways, as follows:

\section{a) Questionnaire Method}

The research data collection method is carried out by making a list of questions which are then submitted to students as respondents to fill in the answers.

\section{b) Documentary method}

It is a method of collecting research data with documentation, in other words collecting data from existing documents, so that the researcher can obtain records relating to research. This documentation method is carried out to obtain data that has not been obtained through the Quesionary Method.

In preparing the instruments used from the Likert Scale model that is with the option Very True, Not True, sometimes True, True, Very true. Each option is given a weight ranging from 5 for Very True, 4 for Not True, 3 sometimes True, 2 True, until the weight of 1 for the Very True option

In compiling the Questionnaire, the author uses references from several figures, namely: David King with SISRI 24 for the Spiritual Intelligence questioner and Reuven Bar-On with EQ-i125 for the Emotional Intelligence questioner.

\section{c. Hyphothesis}

The proposed research hypothesis consists of a major hypothesis and three minor hypotheses. The major hypotheses proposed are as follows: There is a positive relationship between emotional intelligence and spiritual intelligence with student Academic achievement. The higher the emotional intelligence and spiritual intelligence of a person, the higher the Academic Achievement. The lower the emotional intelligence and spiritual intelligence of a person, the lower the Academic achievement will be. The major hypothesis will be accepted if three minor hypotheses submitted by the researcher are accepted. The minor hypotheses proposed by researchers are as follows:

1. Is there any positive influence on Emotional Intelligence on the Academic Achievement of Private Madrasah Aliyah Students in South Jakarta?

2. Is there any positive influence on students' Spiritual Intelligence on Student Achievement in Private Madrasah Aliyah in South Jakarta?

3. Is there any positive influence of students' emotional intelligence and spiritual intelligence together on student achievement in Madrasah Aliyah Private in South Jakarta?

\section{DISCUSSION AND RESULTS}

The results of the research instrument test using the validity and reliability test for each variable questionnaire, are ; 
Validitas Item Test : From the results of calculations using the SPSS 23 program, out of 125 items for the Emotional Intelligence (X1) variable questionnaire, there were only 37 valid questionnaire items

From the results of calculations using the SPSS 23 Program out of 24 Spiritual Intelligence variable (X2) questionnaire items, all questionnaire items were declared valid

Reliabilitas Item Test : From the results of calculations using the SPSS 23 program, for the Emotional Intelligence (X1), Alpha values of 0.892, with $r$ tables in the 0.05 significance search with 2-tailed test and the amount of data $(n)=100$, then the rtable can be 0.1966 . Therefore the value of $r$ count $=0.892>r$ table $=0.1966$, it can be concluded that the items are reliable.

From the results of calculations using the SPSS 23 Program out of 24 Spiritual Intelligence variable (X2), the Alpha value of 0.862 can be obtained, this value is then compared with the value of rtable, the $\mathrm{r}$ table is found at the 0.05 significance by 2 -sided test and the amount of data $(\mathrm{n})=100$, then the rtable is 0,1966 . Because the calculated value $=0.862>$ rtable $=$ 0.1966 , it can be concluded that the items are reliable.

For the hypothesis testing is using multiple linear regression analysis. From the results of calculations using the SPSS 23 Program the highest score from the questionnaire score of the Emotional Intelligence Variable (X1) is 487 and the lowest score is 310 , the middle value is 389 , the value that often appears is 405 and the average value is 390.70 .

From the results of calculations using the SPSS 23 Program the highest score from the questionnaire score of the Spiritual Intelligence Variable score (X2) is 89 and the lowest score is 43 , the middle value is 69 , the value that often appears is 62 and the average value is 68.31 . From the results of calculations using the SPSS 23 Program the highest score from the questionnaire score of the the Student Academic Achievement Questionnaire score (Y) is 89 and the lowest score is 62 , the middle value is 80 , the value that often appears is 80 and the average value is 78.16 .

\section{Coefficients}

\begin{tabular}{|c|c|c|c|c|c|}
\hline \multirow[b]{2}{*}{ Model } & \multicolumn{2}{|c|}{$\begin{array}{c}\text { Unstandardized } \\
\text { Coefficients }\end{array}$} & \multirow{2}{*}{$\begin{array}{c}\text { Standardized } \\
\text { Coefficients } \\
\text { Beta }\end{array}$} & \multirow[b]{2}{*}{$\mathrm{t}$} & \multirow[b]{2}{*}{ Sig. } \\
\hline & $\alpha$ & Std. Error & & & \\
\hline 1 (Constant) & 91.345 & 11.782 & & 7.753 & .000 \\
\hline EmotionalIntelligence & -.017 & .031 & -.059 & -.560 & .577 \\
\hline Spiritual Intelligence & -.094 & .077 & -.127 & -1.220 & .225 \\
\hline
\end{tabular}

a. Dependent Variable: Student Academic Achievement

Based on the table above we can get the regression equation model as follows:

$\mathrm{Y}=\alpha+\beta 1 \mathrm{X} 1+\beta 2 \mathrm{X} 2$ 
$\mathrm{Y}=91,345+017 \mathrm{X} 1+0,094 \mathrm{X} 2$

The constant $(\alpha)$ of 91.345 means that if Emotional Intelligence (X1) and Spiritual Intelligence (X2) are absent or the value is 0, then the Student Achievement level will be 91.345.

The regression coefficient of the students' emotional intelligence variable (X1) was 0.017 , meaning that if the students' emotional intelligence (X1) was increased by 1 unit, the students' Academic achievement experienced a relatively small increase of 0.017 units.

The regression coefficient of the variable of students' spiritual intelligence (X2) was 0.094, meaning that if the students' spiritual intelligence (X1) increased by 1 unit, the students' Academic achievement experienced a relatively small increase of 0.094 units.

Multiple regression analysis tabel Model Summary ${ }^{b}$

\begin{tabular}{|r|r|r|r|r|}
\hline Model & $R$ & $R$ & & \\
\hline 1 & .154 & .024 & .004 & \\
\hline
\end{tabular}

a. Predictors: (Constant), Emotional, Spiritual Intelligence

b. $\quad$ Dependent Variable: Academic Student Achievement

Based on the above output obtained $\mathrm{R}$ value of 0.154 . This shows that there is a very low influence between emotional intelligence (X1) and spiritual intelligence (X2) on student achievement.

Researcher also using Partial regression coefficient test ( $\mathrm{T}$ test), $\mathrm{T}$ test is used to determine whether the independent variable partially influences the dependent variable. From the results of calculations using SPSS 23 the output can be as follows:

\section{T test Coefficients ${ }^{\mathrm{a}}$}

\begin{tabular}{|c|c|c|c|c|c|}
\hline \multirow[b]{2}{*}{ Model } & \multicolumn{2}{|c|}{ Unstandardized Coefficients } & \multirow{2}{*}{$\begin{array}{c}\text { Standardized Coefficients } \\
\text { Beta }\end{array}$} & \multirow[b]{2}{*}{$t$} & \multirow[b]{2}{*}{ Sig. } \\
\hline & B & Std. Error & & & \\
\hline 1 (Constant) & 91.345 & 11.782 & & 7.753 & .000 \\
\hline EmotionalIntelligence & -.017 & .031 & -.059 & -.560 & .577 \\
\hline
\end{tabular}




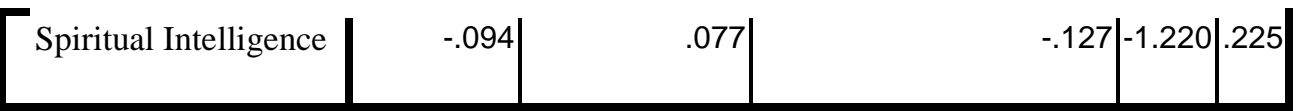

a. Dependent Variable: Academic Student Achievement

Based on the results of the above output we can know the value of $t$ of each variable.

Effect of Emotional Intelligence (X1) on Student Academic Achievement (Y)

Hypothesis:

Ho: Emotional Intelligence does not have a significant effect on Student Academic Achievement.

Ha: Emotional Intelligence has a significant influence on Student Academic Achievement.

Based on the data above, a tcount of 0.560 can be obtained. This shows that the value of $t$ is smaller than t table 1.664 and sig value is greater than 0.05 . Thus Ho is accepted and Ha is rejected. This means that the variable Emotional Intelligence (X1) does not have a significant effect on Student Academic Achievement.

Effect of Spiritual Intelligence (X2) on Student Academic Achievement (Y)

Hypothesis:

Ho: Spiritual Intelligence does not have a significant effect on Student Academic Achievement.

Ha: Spiritual Intelligence has a significant influence on Student Academic Achievement.

Based on the above output, the tcount value of 1,220 is obtained with a sig value of 0.225 , which shows that the tcount value is smaller than the table of 1,664. Thus Ho is accepted and $\mathrm{Ha}$ is rejected. This means that the variable Spiritual Intelligence (X2) does not have a significant effect on Student Academic Achievement.

Researcher also using Simultaneous regression coefficient test ( $\mathrm{F}$ test), $\mathrm{F}$ test is used to determine whether the independent variables together have a significant effect on the dependent variable.

Hypothesis:

Ho: Emotional Intelligence (X1) and Spiritual Intelligence (X2) together do not have a significant effect on Student Learning Outcomes (Y).

Ha: Emotional Intelligence (X1) and Spiritual Intelligence (X2) together have a significant influence on Student Learning Outcomes (Y).

The results of the independent variable influence of Emotional Intelligence (X1) and Spiritual Intelligence on Student Learning Achievement (Y) using SPSS 23 can be output as follows:

\begin{tabular}{|l|l|l|l|l|l|}
\hline \multicolumn{6}{c|}{ ANOVA $^{\mathrm{b}}$} \\
\hline Model & Sum of Squares & df & Mean Square & F & Sig. \\
\hline 1 Regression & 145.437 & 2 & 72.718 & 1.184 & $.310^{\mathrm{a}}$ \\
Residual & 5958.008 & 97 & 61.423 & & \\
Total & 6103.445 & 99 & & & \\
\hline
\end{tabular}

Predictors: (Constant), Spiritual Intelligence, Emotional Intelligence

Dependent Variable: Student's Academic achievement 
Based on the above output, the F count value of 1.184 is obtained with a sig value of 0.310 . It shows that the F count value is smaller than the F table value 3.09. Thus Ho is accepted and $\mathrm{Ha}$ is rejected. This means that Emotional Intelligence (X1) and Spiritual Intelligence (X2) together do not have a significant effect on Student Academic Achievement (Y).

Based on statistic test : There is an insignificant effect on Emotional Intelligence (X1) and Spiritual Intelligence (X2) together on Student Academic Achievement (Y).

With a value of $\mathrm{R}$ Square $=0.024$ which implies that the influence of independent variables (Emotional Intelligence (X1) and Spiritual Intelligence (X2) together on the dependent variable (Student Achievement $(\mathrm{Y})$ ) is $2.4 \%$, while the rest influenced by other variables.

Quoted from the results of a similar doctoral study conducted by Merial J. Smartt from Liberty University - Lynchburg, USA, in 2014 entitled, "The Relationship of Spiritual Intelligence to Achievement of Secondary Students" from the results of the study found the results were found to be very small, and also the result of dissertation research from Barbara A Fatum of The University of San Francisco, in 2008 entitled "The Relationship Between Emotional Intelligence and Academic Achievement in Elementary School Children."[8] The results showed the two correlations were weak but there was a significant correlation between the two health barometers and values in English Language Arts. Therefore this research confirm the previous research that there was insignificant / very small/ weak relationship between spiritual intelligence and student Academic achievement.

From the results of this analysis there will arise several possibilities, Current student Academic achievement is not significantly influenced by other types of intelligences, but emotional and spiritual intelligence because: (I) there are an indications that the report cards received by students so far considered as benchmarks of student achievement are still unable to accommodate Emotional and Spiritual Intelligence, ( II) The benchmarks used by researchers are still unable to measure students' emotional and spiritual intelligence, (III) The lack of sample used by the author so that it affects the values of the variable itself.

\section{CONCLUSION}

There is an insignificant effect on Emotional Intelligence (X1) on Student Academic Achievement (Y). The magnitude of the effect of Emotional Intelligence (X1) on Student Academic Achievement (Y) can be seen from the value of $r$, from the results of the analysis using SPSS 23.0 in the value of $r=0.017$.

There is an insignificant effect of Spiritual Intelligence (X2) on Student Academic Achievement (Y). The magnitude of the influence of Spiritual Intelligence (X2) on Student Academic Achievement (Y) can be seen from the value of $r$, from the results of the analysis using SPSS 23.0 in the value of $r=0.094$.

There is an insignificant effect on Emotional Intelligence (X1) and Spiritual Intelligence (X2) together on Student Academic Achievement (Y).

With a value of $\mathrm{R}$ Square $=0.024$ which implies that the influence of independent variables (Emotional Intelligence $(\mathrm{X} 1)$ ) and Spiritual Intelligence (X2) together on the dependent variable (Student Achievement (Y)) is $2.4 \%$, while the rest influenced by other variables. 
Phenomena have been found in research, Based on conclusion some recomendation that can be revealed are as follows:

For students, teachers and parents need to continue to improve Emotional Intelligence and Spiritual Intelligence of Students, So the Student can be more ready to achieve their life goals, not only on their study but also for their social life or other.

For Principals and Education Offices and Indonesian culture, it is necessary to reformulate student report cards that can accommodate other types of intelligence, not only Intelligence Quotient but also Emotional Quotient and Spiritual Quotient.

For academics and the community, further research is needed to test the theories of emotional intelligence, spiritual intelligence and Academic achievements or other variables that can develop theories that can later be used as a foundation of science and community development to develop civil society.

\section{REFERRENCE}

[1] Merial J. Meritt, and Smartt Merial,“ The Relationship of Spiritual Intelligence to $\begin{array}{llll}\text { Achievement } & \text { of } & \text { Secondary } & \text { Students, “ }\end{array}$ https://digitalcommons.liberty.edu/doctoral/820/, Retrieved 28 August 2019

[2] Universitas Gajah Mada, Permendikbud 104 tahun 2014, http://luk.staff.ugm.ac.id/atur/bsnp/Permendikbud104-2014PenilaianHasilBelajar.pdf, Retrieved 28 August 2019

[3] Goleman Daniel,"Emotional Intelligence (terjemahan),“ Jakarta : PT. Gramedia Pustaka Utama. 2000

[4] Cooper R K and Sawaf,"A Executive EQ Kecerdasan Emosional dalam Kepemimpinan dan Organisasi, Jakarta : Gramedia, 1998

[5] Ary Ginanjar,“ Rahasia sukses membangun kecerdasan emosi dan spiritual, “ Jakarta : Arga Wijaya Persada, 2001

[6] Danah Zohar and Marshall, alihbahasa Rahmani Astuti dkk,“ SQ: Spiritual Intelligence The ultimate intelligence, "Bandung : Mizan Media Utama, 2007

[7] David King,"RETHINKING CLAIMS OF SPIRITUAL INTELLIGENCE: A DEFINITION, MODEL, AND MEASURE“ alih bahasa oleh Anaz, (2008), http://www.davidbking.net/thesis.pdf Retrieved 28 August 2019

[8] Barbara A Fatum entitled "The Relationship Between Emotional Intelligence and Academic Achievement in Elementary School Children,"“ 2008, https://repository.usfca.edu/diss/265/ Retrieved 28 August 2019 